\title{
Experimental investigation and numerical simulation of CO oxidation with $\mathrm{HCl}$ addition
}

\author{
Dongyin $\mathrm{Wu}^{\mathrm{a}}$, Yuhao Wang ${ }^{\mathrm{a}, \mathrm{b}}$, Xiaolin Wei ${ }^{\mathrm{b}, *}$, Sen $\mathrm{Li}^{\mathrm{b}}$, Xiaofeng Guo ${ }^{\mathrm{c}, \mathrm{d}}$ \\ ${ }^{a}$ School of Energy and Power Engineering, Xi'an Jiaotong University, Xi'an 710049, China

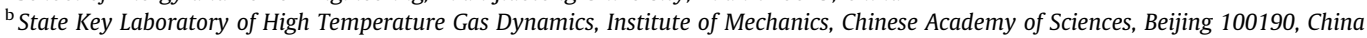 \\ ' SINOPEC Star Petroleum Co., Ltd. (Sinopec Star), New Energy Researching Institute, Beijing 100083, China \\ ${ }^{\mathrm{d}}$ China National Research and Technology Center of Geothermal Energy, Beijing 100083, China
}

\section{H I G H L I G H T S}

- Experiment is operated under different temperatures and equivalence ratios in an EFR.

- Simulation is conducted by CFD coupled with reduced reaction mechanism.

- Inhibition of $\mathrm{HCl}$ on $\mathrm{CO}$ oxidation is affected by equivalence ratio and temperature.

- $\mathrm{HCl}$ inhibits $\mathrm{CO}$ oxidation mainly through suppressing $\mathrm{OH}$ production.

\section{A R T I C L E I N F O}

\section{Article history:}

Received 20 January 2016

Received in revised form 23 March 2016

Accepted 24 March 2016

Available online 30 March 2016

\section{Keywords:}

Inhibition effect

CO oxidation

Reduced mechanism

$\mathrm{HCl}$

EFR
G R A P H I C A L A B S T R A C T

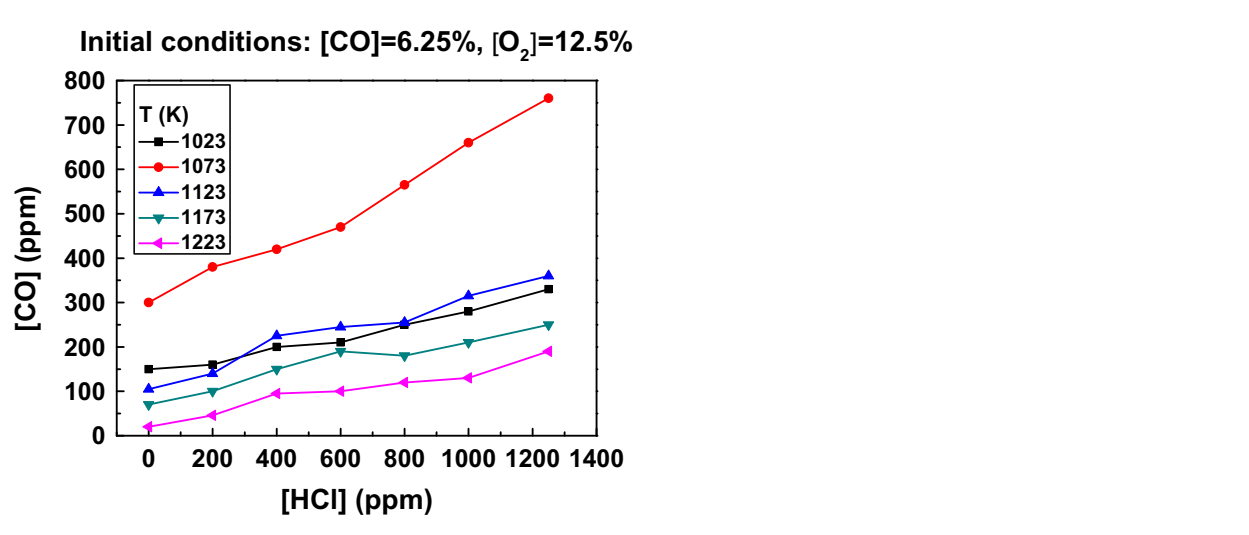

A B S T R A C T

Chlorine is rich in biomass and some coals and significantly released as $\mathrm{HCl}(\mathrm{g})$ during combustion process, and this promotes the recombination of free radicals $\mathrm{OH}, \mathrm{H}, \mathrm{O}$, and $\mathrm{HO}_{2}$ and further influences $\mathrm{CO}$ oxidation. In this paper, the inhibition effect of $\mathrm{HCl}$ on $\mathrm{CO}$ oxidation is investigated by experiment and numerical simulation. The experiment is operated under different reaction zone temperatures and equivalence ratios in an entrained flow reactor. And the numerical simulation is conducted by CFD software coupled with reduced reaction mechanism. The results indicate that $\mathrm{HCl}$ addition obviously inhibits $\mathrm{CO}$ oxidation under oxygen-rich condition, and the inhibition enhances as $\mathrm{HCl}$ concentration rises, but weakens as temperature increases. Under chemical equivalent and oxygen-lean conditions, the inhibition effect is limited.

(c) 2016 Elsevier Ltd. All rights reserved.

\section{Introduction}

Chlorine is rich in biomass and some coals, and it is either released or retained in ash during combustion, which causes fouling, slagging, deposition or corrosion in the boiler [1-6]. Compared with coals, biomass has high content of chlorine, and significant

\footnotetext{
* Corresponding author.
}

amount of it is released as $\mathrm{KCl}(\mathrm{g}), \mathrm{NaCl}(\mathrm{g})$, or $\mathrm{HCl}(\mathrm{g})$, etc. [7$13,19]$, which promotes the recombination of free radicals $\mathrm{OH}, \mathrm{H}$, $\mathrm{O}$, and $\mathrm{HO}_{2}$ at high temperature and decreases their total amount, and results in an inhibition effect on CO oxidation [14-26].

Roesler et al. [14-16] developed a detailed kinetic model for moist $\mathrm{CO}$ oxidation inhibited by $\mathrm{HCl}$. The model was validated against experimental data and showed good agreement. The results revealed that trace quantity of $\mathrm{HCl}$ could significantly 
inhibit CO oxidation. At high temperature, the chain termination reactions in the inhibitory cycles were primarily $\mathrm{H}+\mathrm{Cl}$ $+\mathrm{M} \leftrightarrow \mathrm{HCl}+\mathrm{M}$ and $\mathrm{Cl}+\mathrm{Cl}+\mathrm{M} \leftrightarrow \mathrm{Cl}+\mathrm{M}$. But the principal chain terminating step at $1000 \mathrm{~K}$ was found to be $\mathrm{Cl}+\mathrm{HO}_{2} \leftrightarrow \mathrm{HCl}+\mathrm{O}_{2}$. Glarborg [19] investigated how trace species affects overall combustion process, and he also established a general reaction model. It is presumed that inhibition took place through A cycles: $\mathrm{HCl}$ $+\mathrm{H} \leftrightarrow \mathrm{H}_{2}+\mathrm{Cl}$ and $\mathrm{HCl}+\mathrm{OH} \leftrightarrow \mathrm{H}_{2} \mathrm{O}+\mathrm{Cl}$. As $\mathrm{Cl}$ concentration built up in the post-flame region, the inhibiting cycles competed with B cycles: $\mathrm{Cl}+\mathrm{HO}_{2} \leftrightarrow \mathrm{ClO}+\mathrm{OH}$ and $\mathrm{ClO}+\mathrm{CO} \leftrightarrow \mathrm{Cl}+\mathrm{CO}_{2}$, which corresponded to overall reaction: $\mathrm{CO}+\mathrm{HO}_{2} \leftrightarrow \mathrm{CO}_{2}+\mathrm{OH}$. The competition between $\mathrm{A}$ and $\mathrm{B}$ cycles determined whether the chlorine had an overall promoting or inhibiting effect on $\mathrm{CO}$ oxidation. Wei et al. [22] investigated the influence of $\mathrm{HCl}$ on $\mathrm{CO}$ emission in combustion, the results indicated that $\mathrm{HCl}$ not only promoted the recombination of radicals $\mathrm{O}, \mathrm{H}$, and $\mathrm{OH}$, but also accelerated the chemical equilibration of radicals. The influence of $\mathrm{HCl}$ on the radicals mainly occured at $800-1200 \mathrm{~K}$. Wang and Chi [24] constructed a kinetic model of $\mathrm{CO} / \mathrm{H}_{2} / \mathrm{Cl}_{2}$ mixture oxidation, the results illustrated $\mathrm{CO}$ conversion varied inversely with $\mathrm{Cl} / \mathrm{H}$ mole ratio and increased with temperature. The reaction of $\mathrm{HCl}$ $+\mathrm{OH} \leftrightarrow \mathrm{H}_{2} \mathrm{O}+\mathrm{Cl}$ decreased $\mathrm{OH}$ concentration and led to low $\mathrm{CO}$ conversion, and $\mathrm{CO}$ oxidation was mainly through $\mathrm{H}+\mathrm{O}_{2} \leftrightarrow \mathrm{HO}_{2}$. The rising of reaction temperature resulted in higher $\mathrm{OH}$ concentration and larger reaction rate of $\mathrm{CO}+\mathrm{OH} \leftrightarrow \mathrm{CO}_{2}+\mathrm{H}$. Pelucchi et al. [25] updated the high-temperature chlorine chemistry and re-examined the inhibition mechanisms involving $\mathrm{HCl}$ and $\mathrm{Cl}_{2}$. It is found that the reactions containing $\mathrm{HCl}$ were the chain propagation reactions: $\mathrm{HCl}+\mathrm{O} \leftrightarrow \mathrm{Cl}+\mathrm{OH}, \mathrm{HCl}+\mathrm{OH} \leftrightarrow \mathrm{H}_{2} \mathrm{O}+\mathrm{Cl}$ and $\mathrm{Cl}$ $+\mathrm{HO}_{2} \leftrightarrow \mathrm{ClO}+\mathrm{OH}$, together with the termination reaction: $\mathrm{Cl}$ $+\mathrm{HO}_{2} \leftrightarrow \mathrm{HCl}+\mathrm{O}_{2}$. Besides the investigations mentioned above, some other studies related to the influence of HX-type or halogen gas on fuel oxidation also had significant assistance to our research [27-31].

In this paper, the inhibition effect of $\mathrm{HCl}$ addition on $\mathrm{CO}$ oxidation is investigated by experimental and numerical simulation study. At present, most experiment and simulation studies of $\mathrm{HCl}$ on $\mathrm{CO}$ oxidation are focused on reactions in post-combustion, and the $\mathrm{CO}$ concentration is rather low (less than 1\%) [14-16]. However, CO concentration can be up to $5 \%$ in the initialcombustion stage. Therefore, CO concentration of $1-6 \%$ is investigated. The experimental study is operated in an entrained flow reactor at different reaction zone temperatures and equivalence ratios. The numerical simulation is conducted by CFD software coupled with reduced reaction mechanism involving 12 species and 6 reactions.

\section{Experimental system}

Based on one-dimensional reaction flow model, an entrained flow reactor (EFR) system is applied to investigate the effect of $\mathrm{HCl}$ addition on $\mathrm{CO}$ combustion.

Fig. 1(a) shows the structure of EFR system, which is similar to those used in DTU (Technical University of Denmark) [32,33]. At the entrance of the reactor, a spherical end of the internal tube has four small drilled orifices. Through the orifices, the reactants can flow out vertically with the tube axis and quickly mix with the main gas flow. The main airflow of the reactants containing $\mathrm{O}_{2}, \mathrm{H}_{2} \mathrm{O}, \mathrm{HCl}$ and $\mathrm{N}_{2}$ is sent into the entrance of the EFR through a quartz reaction tube with a diameter of $14 \mathrm{~mm}$ and length of $590 \mathrm{~mm}$. The second airflow with pure CO comes into the EFR through the four orifices and mixes with the main airflow. The total volumetric flow rate is $4 \mathrm{NL} / \mathrm{min}$. The heat loss is minimized with electric resistance heater that maintains the reactor tube at the

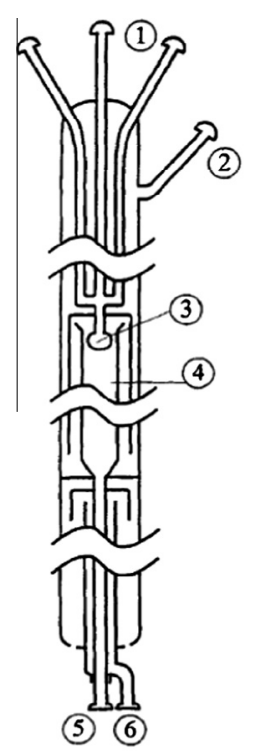

(a)

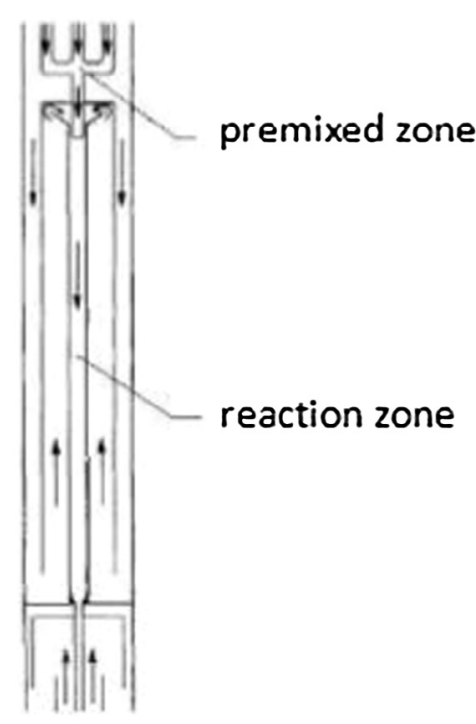

(b)
Fig. 1. Experimental system: (a) structure of EFR: (1) CO inlet (2) main gas inlet (3) nozzle (4) reaction tube (5) off-gas outlet (6) cooling gas inlet; (b) flow state in the EFR.

initial reaction temperature. $\mathrm{CO}$ concentration is measured by a Land gas analyzer.

In Fig. 1(b), the front concentric tube and the nozzle together form a narrow interlayer, which corresponding to the premixed zone. CO sprays into the premixed zone through the nozzle and strongly mixes with the main airflow. Then, the mixing gas rapidly reach the wall and flow into the reaction zone to finish the combustion. The mixing process is quite violent and complex, which related to a turbulent flow. However, due to the small size of the premixed zone and the low flow rate of the mixing gas, the Reynolds number tends to be not very high.

\section{Chemical reaction model}

\subsection{Model establishment}

A self-written program for chemical mechanism reduction is developed to implement the detailed mechanism [14,16] into CFD program. As a preliminary exploration in the present work, based on the Connect and PCAF methods [34], a skeletal mechanism (see Table 1 ) is obtained by reducing a detailed mechanism including 19 species and 140 irreversible reactions and containing $\mathrm{CO} / \mathrm{O}_{2} / \mathrm{HCl} / \mathrm{H}_{2} \mathrm{O} / \mathrm{N}_{2}$. Then, the QSS (quasi-steady-state) assumption method is used to distinguish the QSS species, the reduced mechanism involving 12 species and 6 reactions is obtained, as shown in Table 2. The reaction rates of the reduced mechanism are given in Table 3.

\subsection{Model validation}

To validate the reduced mechanism, the SENKIN code in CHEMKIN is used to calculate with the detailed, skeletal and reduced mechanism respectively, and the results show high accuracy for the reduced mechanism, as shown in Fig. 2. Coupling the reduced mechanism with CFD software, the effect of trace amount of $\mathrm{HCl}$ on $\mathrm{CO}$ combustion is simulated at different $\mathrm{HCl}$ concentration, reaction zone temperature, and equivalence ratio. 
Table 1

The skeletal mechanism (16 species, 45 reactions).

\begin{tabular}{|c|c|c|}
\hline \multicolumn{3}{|c|}{ Species: $\mathrm{Ar}, \mathrm{Cl}, \mathrm{Cl}_{2}, \mathrm{ClO}, \mathrm{CO}, \mathrm{CO}_{2}, \mathrm{H}, \mathrm{HCl}, \mathrm{HOCl}, \mathrm{HO}_{2}, \mathrm{H}_{2}, \mathrm{H}_{2} \mathrm{O}, \mathrm{N}_{2}, \mathrm{O}, \mathrm{O}_{2}, \mathrm{OH}$} \\
\hline 1: $\mathrm{O}+\mathrm{H}_{2} \Rightarrow \mathrm{H}+\mathrm{OH}$ & 16: $\mathrm{H}+\mathrm{H}_{2} \mathrm{O} \Rightarrow \mathrm{OH}+\mathrm{H}_{2}$ & $31: 2 \mathrm{Cl}+\mathrm{M} \Rightarrow \mathrm{Cl}_{2}+\mathrm{M}$ \\
\hline 2: $\mathrm{H}+\mathrm{OH} \Rightarrow \mathrm{O}+\mathrm{H}_{2}$ & $17: 2 \mathrm{OH} \Rightarrow \mathrm{O}+\mathrm{H}_{2} \mathrm{O}$ & 32: $\mathrm{Cl}_{2}+\mathrm{M} \Rightarrow 2 \mathrm{Cl}+\mathrm{M}$ \\
\hline 3: $\mathrm{O}+\mathrm{HO}_{2} \Rightarrow \mathrm{OH}+\mathrm{O}_{2}$ & 18: $\mathrm{O}+\mathrm{H}_{2} \mathrm{O} \Rightarrow 2 \mathrm{OH}$ & 33: $\mathrm{Cl}_{2}+\mathrm{H} \Rightarrow \mathrm{Cl}+\mathrm{HCl}$ \\
\hline $4: \mathrm{O}+\mathrm{CO}(+\mathrm{M}) \Rightarrow \mathrm{CO}_{2}(+\mathrm{M})$ & 19: $\mathrm{OH}+\mathrm{HO}_{2} \Rightarrow \mathrm{O}_{2}+\mathrm{H}_{2} \mathrm{O}$ & 34: $\mathrm{ClO}+\mathrm{O} \Rightarrow \mathrm{Cl}+\mathrm{O}_{2}$ \\
\hline 5: $\mathrm{O}_{2}+\mathrm{CO} \Rightarrow \mathrm{O}+\mathrm{CO}_{2}$ & $20: \mathrm{OH}+\mathrm{CO} \Rightarrow \mathrm{H}+\mathrm{CO}_{2}$ & 35: $\mathrm{Cl}+\mathrm{HO}_{2} \Rightarrow \mathrm{ClO}+\mathrm{OH}$ \\
\hline $6: \mathrm{H}+\mathrm{O}_{2}+\mathrm{M} \Rightarrow \mathrm{HO}_{2}+\mathrm{M}$ & 21: $\mathrm{H}+\mathrm{CO}_{2} \Rightarrow \mathrm{OH}+\mathrm{CO}$ & 36: $\mathrm{ClO}+\mathrm{OH} \Rightarrow \mathrm{Cl}+\mathrm{HO}_{2}$ \\
\hline 7: $\mathrm{H}+\mathrm{O}_{2}+\mathrm{H}_{2} \mathrm{O} \Rightarrow \mathrm{HO}_{2}+\mathrm{H}_{2} \mathrm{O}$ & 22: $\mathrm{Cl}+\mathrm{H}+\mathrm{M} \Rightarrow \mathrm{HCl}+\mathrm{M}$ & 37: $\mathrm{ClO}+\mathrm{CO} \Rightarrow \mathrm{Cl}+\mathrm{CO}_{2}$ \\
\hline 8: $\mathrm{H}+\mathrm{O}_{2}+\mathrm{N}_{2} \Rightarrow \mathrm{HO}_{2}+\mathrm{N}_{2}$ & 23: $\mathrm{Cl}+\mathrm{HO}_{2} \Rightarrow \mathrm{HCl}+\mathrm{O}_{2}$ & 38: $\mathrm{Cl}_{2}+\mathrm{O} \Rightarrow \mathrm{ClO}+\mathrm{Cl}$ \\
\hline 9: $\mathrm{HO}_{2}+\mathrm{N}_{2} \Rightarrow \mathrm{H}+\mathrm{O}_{2}+\mathrm{N}_{2}$ & 24: $\mathrm{HCl}+\mathrm{O}_{2} \Rightarrow \mathrm{Cl}+\mathrm{HO}_{2}$ & 39: $\mathrm{ClO}+\mathrm{Cl} \Rightarrow \mathrm{Cl}_{2}+\mathrm{O}$ \\
\hline 10: $\mathrm{H}+\mathrm{O}_{2} \Rightarrow \mathrm{O}+\mathrm{OH}$ & 25: $\mathrm{HCl}+\mathrm{H} \Rightarrow \mathrm{Cl}+\mathrm{H}_{2}$ & 40: $\mathrm{HOCl} \Rightarrow \mathrm{Cl}+\mathrm{OH}$ \\
\hline 11: $\mathrm{O}+\mathrm{OH} \Rightarrow \mathrm{H}+\mathrm{O}_{2}$ & 26: $\mathrm{Cl}+\mathrm{H}_{2} \Rightarrow \mathrm{HCl}+\mathrm{H}$ & 41: $\mathrm{Cl}+\mathrm{OH} \Rightarrow \mathrm{HOCl}$ \\
\hline 12: $\mathrm{H}+\mathrm{OH}+\mathrm{M} \Rightarrow \mathrm{H}_{2} \mathrm{O}+\mathrm{M}$ & 27: $\mathrm{HCl}+\mathrm{O} \Rightarrow \mathrm{Cl}+\mathrm{OH}$ & 42: $\mathrm{HOCl}+\mathrm{Cl} \Rightarrow \mathrm{Cl}_{2}+\mathrm{OH}$ \\
\hline 13: $\mathrm{H}+\mathrm{HO}_{2} \Rightarrow \mathrm{O}_{2}+\mathrm{H}_{2}$ & 28: $\mathrm{Cl}+\mathrm{OH} \Rightarrow \mathrm{HCl}+\mathrm{O}$ & 43: $\mathrm{Cl}_{2}+\mathrm{OH} \Rightarrow \mathrm{HOCl}+\mathrm{Cl}$ \\
\hline 14: $\mathrm{H}+\mathrm{HO}_{2} \Rightarrow 2 \mathrm{OH}$ & 29: $\mathrm{HCl}+\mathrm{OH} \Rightarrow \mathrm{Cl}+\mathrm{H}_{2} \mathrm{O}$ & 44: $\mathrm{HOCl}+\mathrm{Cl} \Rightarrow \mathrm{ClO}+\mathrm{HCl}$ \\
\hline 15: $\mathrm{OH}+\mathrm{H}_{2} \Rightarrow \mathrm{H}+\mathrm{H}_{2} \mathrm{O}$ & 30: $\mathrm{Cl}+\mathrm{H}_{2} \mathrm{O} \Rightarrow \mathrm{HCl}+\mathrm{OH}$ & 45: $\mathrm{ClO}+\mathrm{HCl} \Rightarrow \mathrm{HOCl}+\mathrm{Cl}$ \\
\hline
\end{tabular}

Table 2

The reduced mechanism (12 species and 6 reactions).

$$
\begin{aligned}
& \text { I: } \mathrm{H}+\mathrm{OH} \Rightarrow \mathrm{H}_{2}+\mathrm{O} \\
& \text { II: } \mathrm{CO}+\mathrm{O}_{2} \Rightarrow \mathrm{CO}_{2}+\mathrm{O} \\
& \text { III: } \mathrm{H}+\mathrm{H}_{2} \mathrm{O} \Rightarrow \mathrm{H}_{2}+\mathrm{OH} \\
& \text { IV: } \mathrm{CO}+\mathrm{OH} \Rightarrow \mathrm{CO}_{2}+\mathrm{H} \\
& \text { V: } 2 \mathrm{O} \Rightarrow \mathrm{O}_{2} \\
& \text { VI: } \mathrm{HCl}+\mathrm{O}_{2} \Rightarrow \mathrm{Cl}+\mathrm{O}+\mathrm{OH}
\end{aligned}
$$

The CFD simulation is used for the experimental system mentioned above. Through a user defined function (UDF), the reduced mechanism established above is implemented into CFD software to describe the chemical reactions in the EFR. In consideration of the low Reynolds number and turbulent flow state, it is not suitable to select a regular laminar or turbulence model for simulation. Thus, the Launder-Sharma turbulence model is used [35], which is a low Reynolds number $k-\varepsilon$ model. Besides, the eddy dissipation concept (EDC) model is applied to solve the interactions between the turbulence and reactions [36], and the in-situ adaptive tabula- tion (ISAT) method is used to accelerate the computing process [37].

\section{Results and discussions}

\subsection{Experiment results}

Figs. 3 and 4 illustrate the influence of $\mathrm{HCl}$ addition on $\mathrm{CO}$ oxidation at different reaction zone temperature and equivalence ratio. Fig. 3 represents the results under the oxygen-rich condition, where $\mathrm{O}_{2}$ concentration of $3 \%$ respectively reacts with CO concentrations of $1 \%, 2 \%, 3 \%, 4 \%, 5 \%$, corresponding to equivalence ratios $\varphi=0.167,0.333,0.500,0.667,0.833$. Fig. 4 represents the comparison results under the oxygen-lean, chemical equivalent, and oxygen-rich conditions, where $\mathrm{CO}$ concentration of $6.25 \%$ reacts with $\mathrm{O}_{2}$ concentrations of $2.5 \%, 3.125 \%, 6.25 \%, 12.5 \%$ ( $\varphi=1.25$, $1.00,0.500,0.250)$ respectively. The experiments are operated under temperatures of $1023 \mathrm{~K}, 1073 \mathrm{~K}, 1123 \mathrm{~K}, 1173 \mathrm{~K}, 1223 \mathrm{~K}$ respectively.

Table 3

The reaction rates of reduced mechanism.

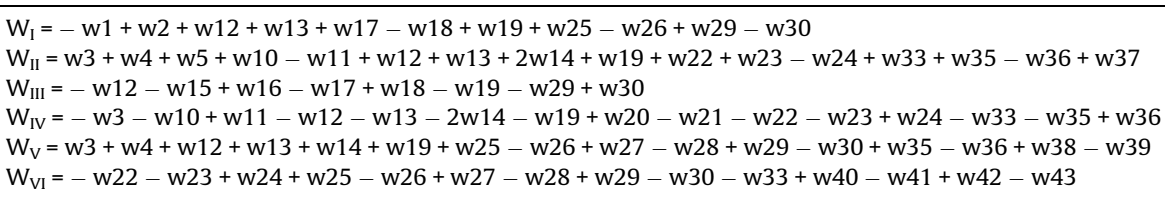

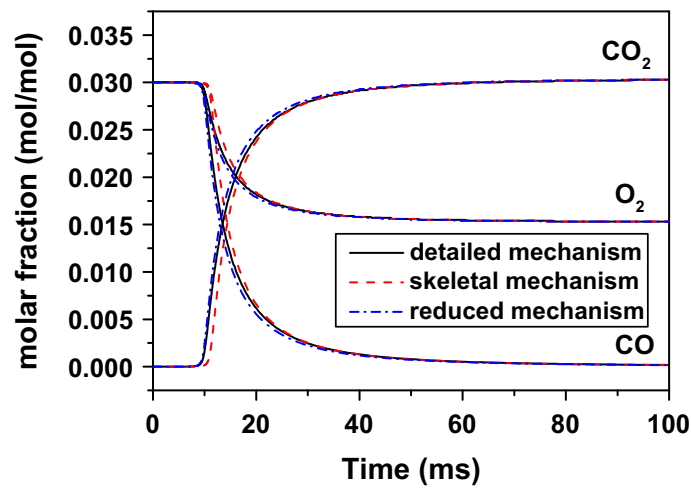

(a) $\mathrm{CO}_{2}, \mathrm{O}_{2}$

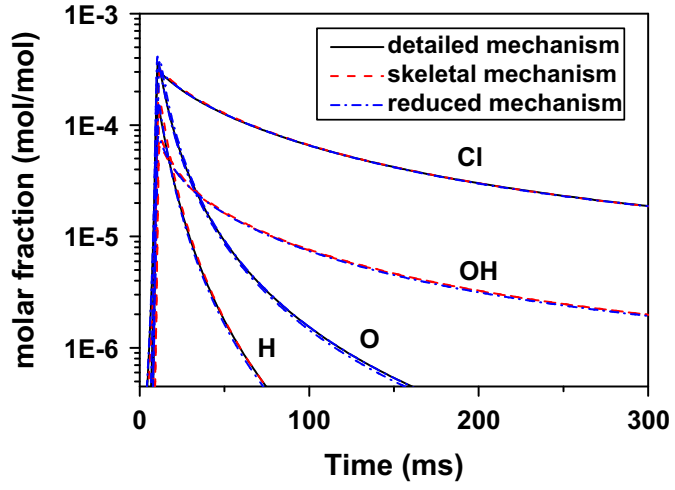

(b) Radicals

Fig. 2. Comparison of the reduced mechanism with the detailed and skeletal one $\left(T=1123 \mathrm{~K}, P=0.1 \mathrm{MPa},\left[\mathrm{O}_{2}\right]=3 \%,[\mathrm{CO}]=3 \%,[\mathrm{HCl}]=600 \mathrm{ppm},\left[\mathrm{H}_{2} \mathrm{O}\right]=1 \%\right)$. 
Initial conditions: $[\mathrm{CO}]=1 \%,\left[\mathrm{O}_{2}\right]=3 \%$

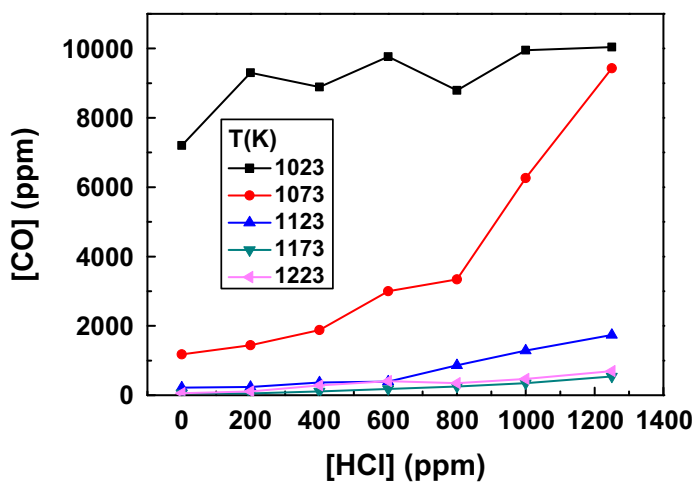

(a)

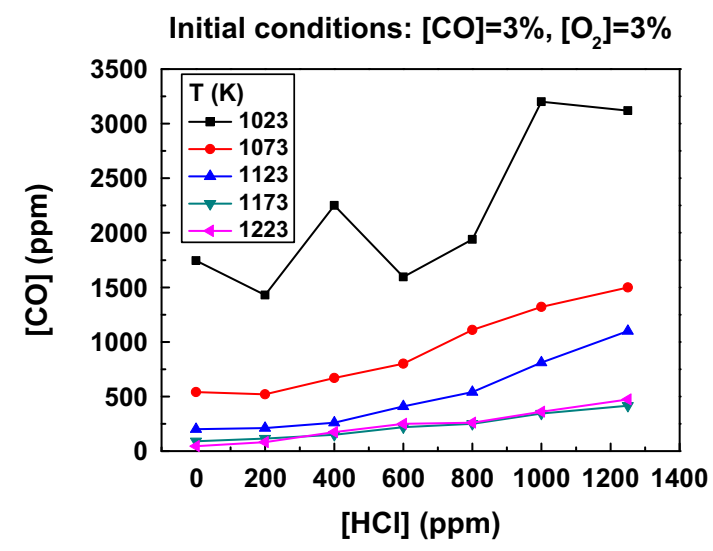

(c)

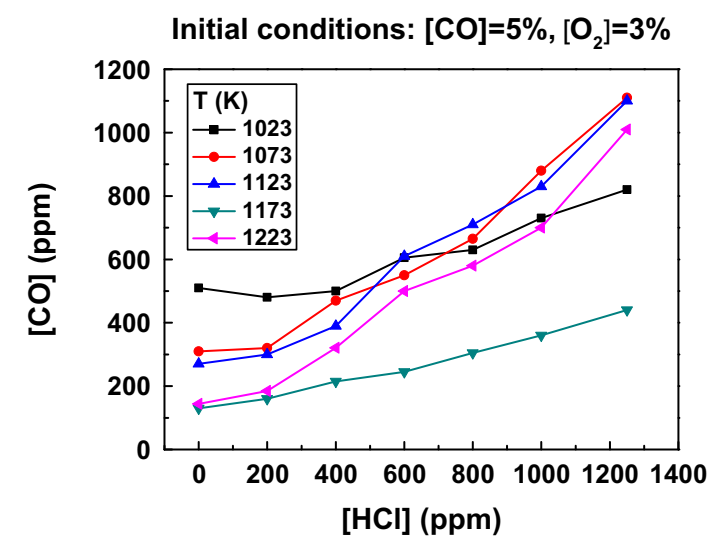

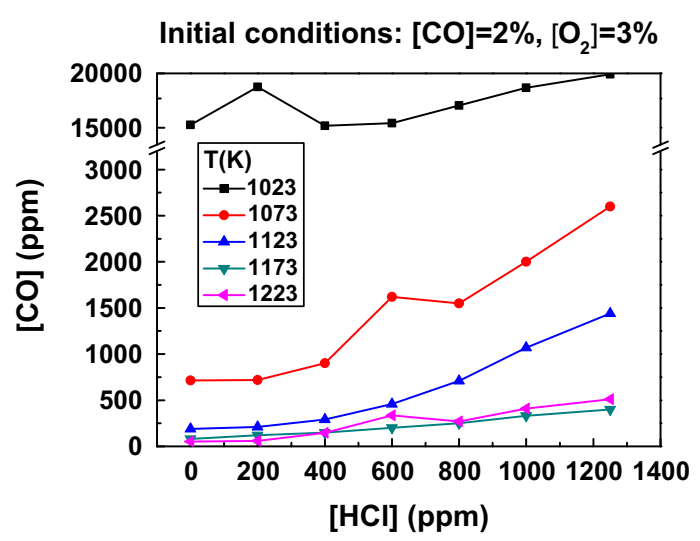

(b)

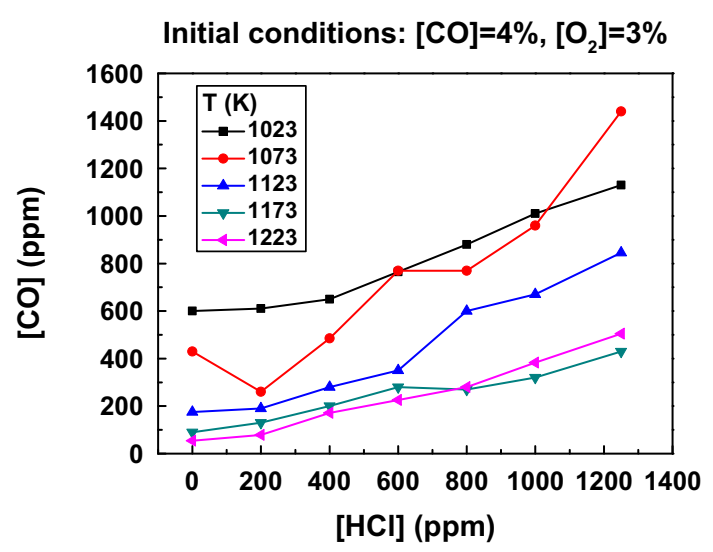

(d)

(e)

Fig. 3. Influence of $\mathrm{HCl}$ on $\mathrm{CO}$ oxidation under oxygen-rich conditions.

Fig. 3 demonstrates that, with the increase of $\mathrm{HCl}$ concentration, $\mathrm{CO}$ concentration also increases, which indicates that $\mathrm{CO}$ oxidation is apparently inhibited. It can be deduced that temperature has a significant influence on $\mathrm{CO}$ oxidation. In Fig. 3(a)-(c), at relatively low temperature $1023 \mathrm{~K}$, the combustion conditions are extremely unsteady and the $\mathrm{CO}$ oxidation rates are rather low. However, CO oxidation at $1123 \mathrm{~K}, 1173 \mathrm{~K}$ and $1223 \mathrm{~K}$ become more rapid and steady. CO concentrations at $1023 \mathrm{~K}$ are approximately ten times higher than those at other temperatures. In Fig. 3(d) and (e), when $\varphi$ is close to chemical equivalent, CO oxidation tends to be stabilized at all temperature conditions and the influence of $\mathrm{HCl}$ on
CO oxidation becomes normal, which indicates that the inhibition effect of $\mathrm{HCl}$ on combustion is more notable. At $1223 \mathrm{~K}$ and $1250 \mathrm{ppm} \mathrm{HCl}$, the $\mathrm{CO}$ concentration can even be ten times more than that without $\mathrm{HCl}$ addition, which illustrates that with rising additional $\mathrm{HCl}$ concentration, $\mathrm{CO}$ oxidation is seriously inhibited and $\mathrm{CO}$ concentration will significantly increase. Of all conditions, almost every $1073 \mathrm{~K}$ CO concentration curve has a considerable fluctuation, and it is interesting to find that $1073 \mathrm{~K}$ is exactly the typical combustion temperature of fluidized bed. Therefore, this series of experimental data have certain engineering significance. 


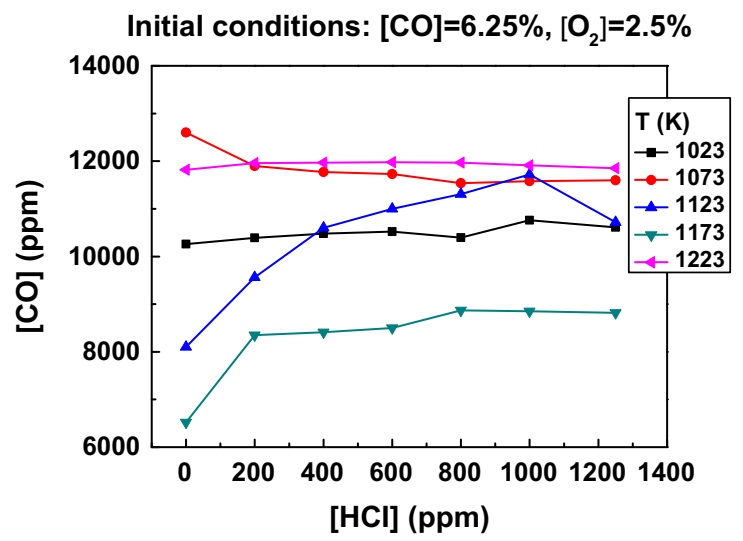

(a)

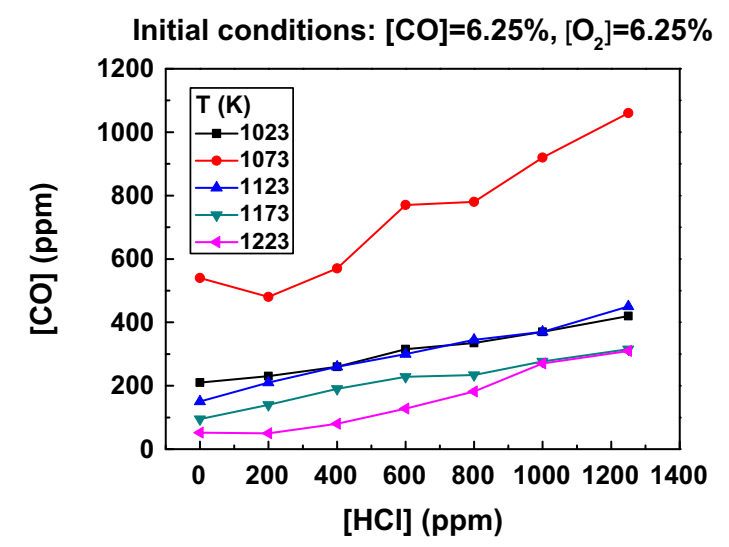

(c)
Initial conditions: $[\mathrm{CO}]=6.25 \%,\left[\mathrm{O}_{2}\right]=3.125 \%$

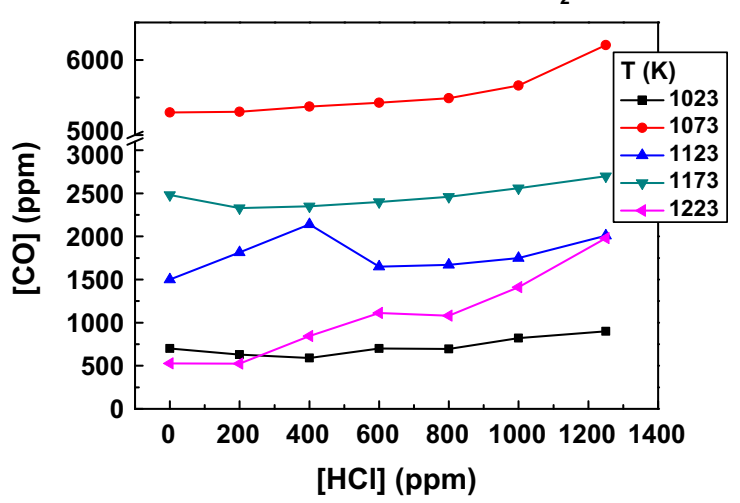

(b)

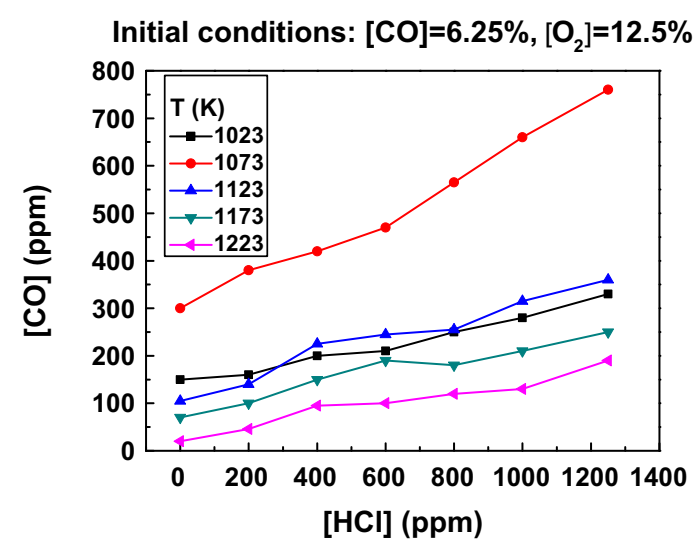

(d)

Fig. 4. Influence of $\mathrm{HCl}$ on $\mathrm{CO}$ oxidation at oxygen-lean, chemical equivalent, and oxygen-rich conditions.

In addition, $\mathrm{CO}$ concentration curves in Fig. 3 are basically identical with the law: with the same $\mathrm{HCl}$ concentration, the higher the reaction zone temperature is, the lower the $\mathrm{CO}$ concentration will be. However, as the equivalence ratio approaches chemical equivalent, this regular distribution will be destroyed, which indicates that the inhibition effect of $\mathrm{HCl}$ is far beyond the promotion effect of temperature on $\mathrm{CO}$ oxidation.

In Fig. 4, most results indicate that, with increasing $\mathrm{HCl}$ concentration, $\mathrm{CO}$ oxidation is apparently inhibited. It also can be inferred from the experiment that temperature significantly affects $\mathrm{CO}$ oxidation. At oxygen-lean condition, as shown in Fig. 4(a), the CO oxidation rate is rather low and unstable. At the highest temperature $1223 \mathrm{~K}$, the $\mathrm{CO}$ concentration reaches maximum, and $\mathrm{HCl}$ has very little influence on $\mathrm{CO}$ oxidation. $\mathrm{HCl}$ can slightly inhibit $\mathrm{CO}$ oxidation at $1123 \mathrm{~K}$ and $1173 \mathrm{~K}$. In a word, the inhibition effect of $\mathrm{HCl}$ on $\mathrm{CO}$ oxidation is quite limited at oxygen-lean condition. At chemical equivalent condition, as shown in Fig. 4(b), CO oxidation tends to be stable at all temperatures, and the inhibition effect of $\mathrm{HCl}$ begins to affect $\mathrm{CO}$ oxidation. At oxygen-rich condition, as shown in Fig. 4 (c) and (d), the CO concentration almost stays at a certain level, and the curves are relatively concentrated. It is easy to find out that the inhibition effect of $\mathrm{HCl}$ on $\mathrm{CO}$ oxidation is strong.

In addition, at oxygen-lean and chemical equivalent conditions, it seems that CO concentration has nothing to do with reaction zone temperature, and this may due to the extremely unsteady combustion.

\subsection{Simulation results}

Fig. 5 illustrates the simulation results of reaction zone temperature and concentration of main species. Compared with CO experimental result, the result shows good agreements for the reduced mechanism when used in CFD simulation. For CO concentration, the simulation underestimates the $\mathrm{CO}$ emission compared with the experimental data, which may be caused by neglecting the chain termination reactions for free radicals on the wall, such as $\mathrm{H}, \mathrm{O}$ and $\mathrm{OH}$. Besides, the heat loss in the experiment may reduce the reacting temperature and cause a relatively high $\mathrm{CO}$ emission. In spite of this, $\mathrm{CO}$ profile trends of both simulation and experiment coincide well, therefore, this simulation method will be used in the following research.

Fig. 6 shows the simulation results for different $\mathrm{HCl}$ concentration at $1123 \mathrm{~K}$ and $\varphi=0.5$. The following expression is used to represent the effect of $\mathrm{HCl}$ on $\mathrm{CO}$ emission when only one factor is variable:

$\Phi=\frac{[\mathrm{CO}]_{\text {out }}}{[\mathrm{CO}]_{\text {in }}}$

where the denominator and numerator are CO flow rate at entrance and exit, respectively. In Fig. 6(a), the simulation $\Phi$ and experiment $\Phi$ both show a upward tendency, which indicates that the fraction of unburned $\mathrm{CO}$ gradually increases with the increase of $\mathrm{HCl}$ concentration, and the inhibited effect of $\mathrm{HCl}$ on $\mathrm{CO}$ emission becomes 


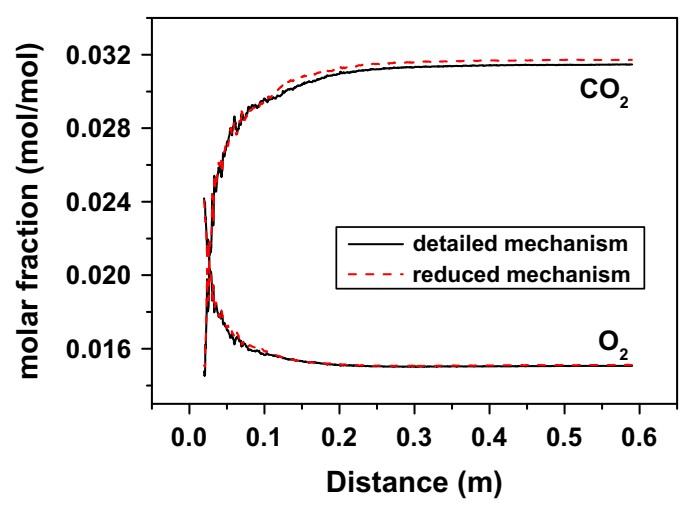

(a) Temperature

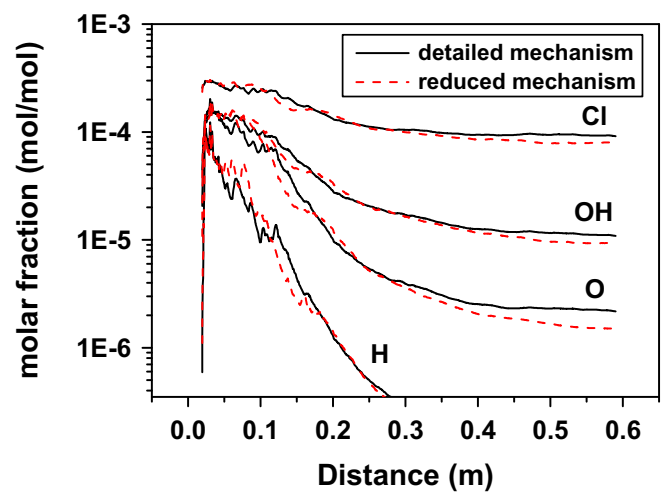

(c) Radicals

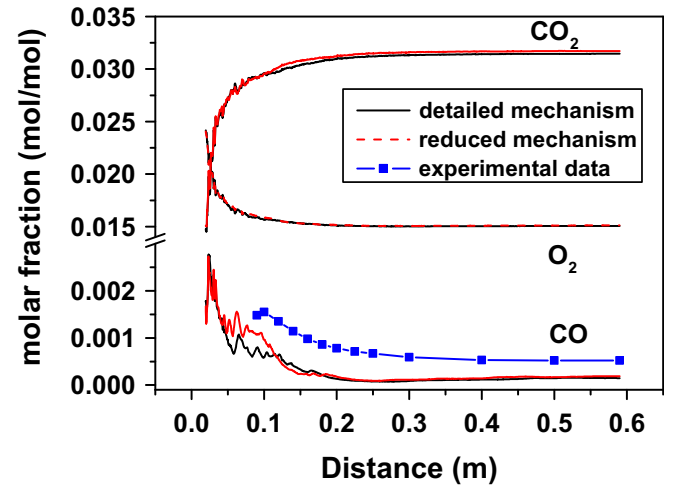

(b) $\mathrm{CO}_{2}, \mathrm{CO}, \mathrm{O}_{2}$

Fig. 5. Comparison of the reduced mechanism with the detailed mechanism and experimental data.

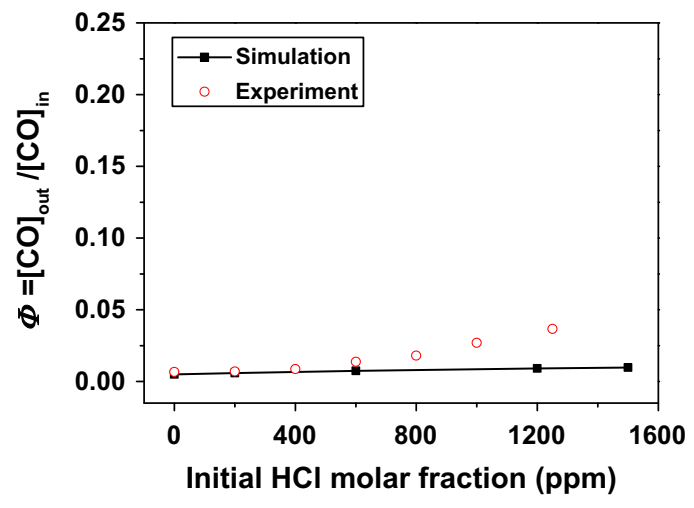

(a) $\Phi$

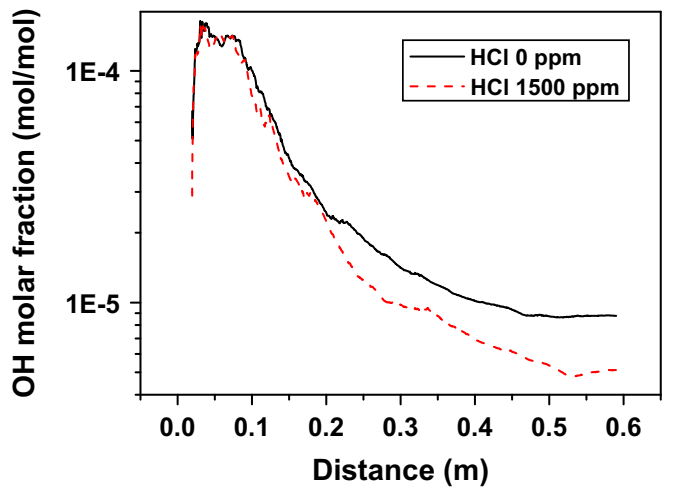

(b) $\mathrm{OH}$

Fig. 6. Simulation results for different $\mathrm{HCl}$ concentrations $\left([\mathrm{CO}]=3 \%,\left[\mathrm{O}_{2}\right]=3 \%, T=1123 \mathrm{~K}\right)$.

obvious when $\mathrm{HCl}$ concentration increases. But it also can be seen that the experiment $\Phi$ are higher than the simulation $\Phi$, and the difference value between them becomes larger and larger with the increase of $\mathrm{HCl}$ concentration. This may due to the complexity of multi-components mixing process at low Reynolds number condition. The numerical model is more ideal, and the mixing process is more homogeneous and sufficient, which is hard to achieve in the experiment. Thus, $\mathrm{CO}$ is better oxidized in the simulation than in the experiment, and this leads to relatively low values of $\Phi$. In Fig. 6(b), as the reaction $\left(\mathrm{CO}+\mathrm{OH} \leftrightarrow \mathrm{CO}_{2}+\mathrm{H}\right)$ is a crucial reaction for $\mathrm{CO}$ oxidation, the $\mathrm{OH}$ simulation results under 0 and $1500 \mathrm{ppm} \mathrm{HCl}$ concentration are also investigated. The result shows that $\mathrm{OH}$ concentration is suppressed when $\mathrm{HCl}$ exists, especially in the late reaction time and non-combustion zone; however, in the combustion zone, $\mathrm{OH}$ production is relatively high due to the promotion effect of $\mathrm{H}_{2} \mathrm{O}$ under high temperature, and then the inhibition effect of $\mathrm{HCl}$ is not obvious.

Fig. 7 shows the simulation results for different temperatures at $600 \mathrm{ppm} \mathrm{HCl}$ and $\varphi=0.5$. In Fig. 7(a), it indicates that the fraction of unburned CO gradually decreases with the increase of temperature, and the inhibited effect of $\mathrm{HCl}$ on $\mathrm{CO}$ emission is weakened as temperature increases. The simulation results and experimental data are quite close to each other. The experiment $\Phi$ is higher than the simulation $\Phi$ because the simulation is more ideal and the CO 


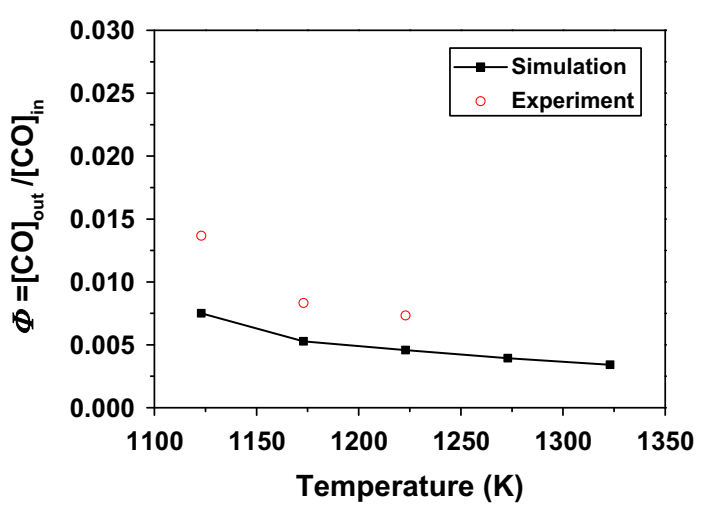

(a) $\Phi$

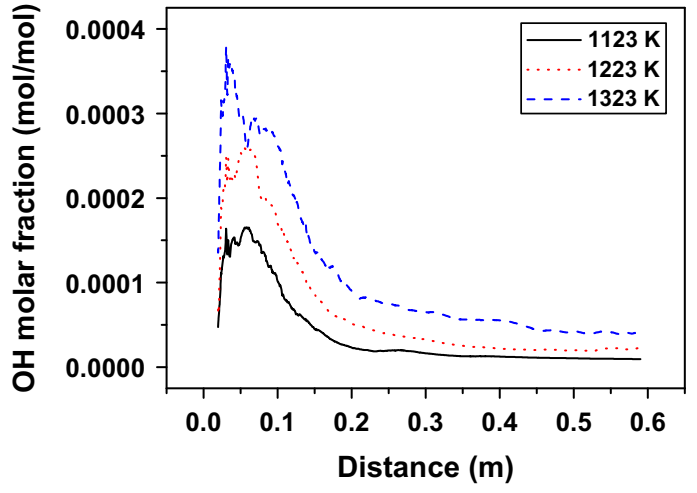

(b) $\mathrm{OH}$

Fig. 7. Simulation results for different temperatures ([CO] $=3 \%,\left[\mathrm{O}_{2}\right]=3 \%,[\mathrm{HCl}]=600 \mathrm{ppm}$ ).

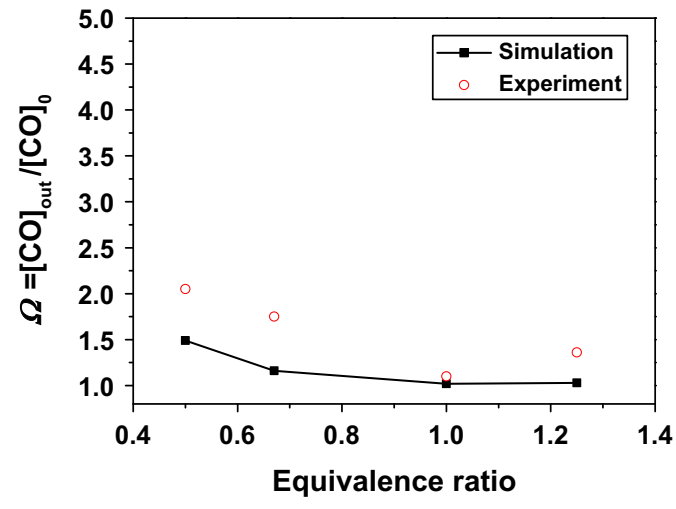

(a) $\Omega$

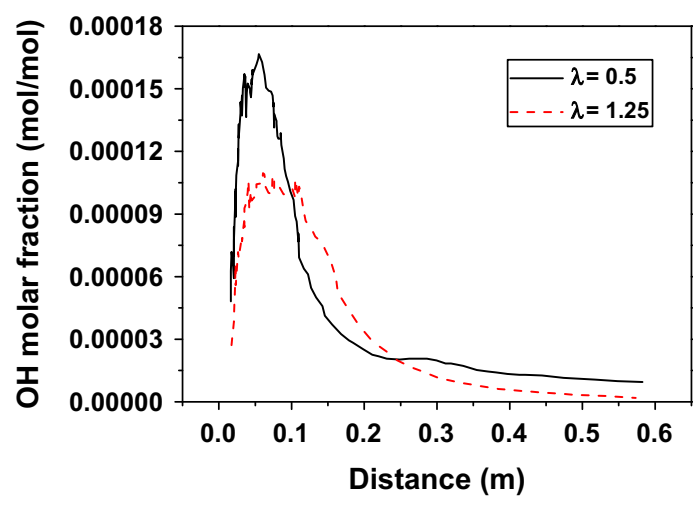

(b) $\mathrm{OH}$

Fig. 8. Simulation results for different equivalence ratios $(T=1123 \mathrm{~K},[\mathrm{HCl}]=600 \mathrm{ppm})$.

oxidation is more sufficient compared with the experiment. In Fig. 7(b), from the simulation result of $\mathrm{OH}$ concentration, it can be seen that the formation of $\mathrm{OH}$ free radical obviously increases when the temperature rises.

When more factors are variable, the following expression is used to represent the effect of $\mathrm{HCl}$ on $\mathrm{CO}$ emission:

$\Omega=\frac{[\mathrm{CO}]_{\text {out }}}{[\mathrm{CO}]_{0}}$

where the denominator and numerator is CO flow rate at the exit with and without $\mathrm{HCl}$ respectively.

Fig. 8 is the simulation result at different equivalence ratios $\left(0.5, \mathrm{O}_{2} 3 \%\right.$ and $\mathrm{CO} 3 \% ; 0.67, \mathrm{O}_{2} 3 \%$ and $\mathrm{CO} 4 \% ; 1.0, \mathrm{O}_{2} 2 \%$ and $\mathrm{CO}$ $4 \% ; 1.25, \mathrm{O}_{2} 2 \%$ and $\mathrm{CO} 5 \%$ ) under temperature $1123 \mathrm{~K}$ and $600 \mathrm{ppm} \mathrm{HCl}$. In Fig. 8(a), the results of both simulation and experiment show that under oxygen-rich conditions, the inhibition effect on CO oxidation is obvious, and the influence becomes more obvious as the equivalence ratio decreases. However, at chemical equivalent and oxygen-lean conditions, the inhibition effect is not obvious. The tendency of simulation $\Omega$ and experiment $\Omega$ coincide with each other. In addition, it is considered that the simulation $\Omega$ is lower than the experiment $\Omega$ mainly due to its more ideal mixing process. At chemical equivalent and oxygen-lean conditions, the oxygen is almost consumed, thus the most important reaction of $\mathrm{OH}$ radical production $\mathrm{H}+\mathrm{O}_{2} \leftrightarrow \mathrm{O}+\mathrm{OH}$ is weakened, the production and concentration of $\mathrm{OH}$ free radical is inhibited, as shown in Fig. 8(b), and thus the effect of $\mathrm{HCl}$ on $\mathrm{OH}$ is limited.

\section{Conclusion}

During the combustion of $\mathrm{CO}$ in an entrained flow reactor (EFR), the inhibition effect of $\mathrm{HCl}$ addition on $\mathrm{CO}$ oxidation is investigated with both experimental and numerical simulation study.

The experimental results show that the addition of $\mathrm{HCl}$ significantly inhibits $\mathrm{CO}$ oxidation at oxygen-rich condition, and the inhibition effect becomes stronger as $\mathrm{HCl}$ concentration increases. $\mathrm{CO}$ concentration can even be ten times more than that without $\mathrm{HCl}$ addition at $1250 \mathrm{ppm} \mathrm{HCl}$ concentration. But, at oxygen-lean and chemical equivalent conditions, the inhibition effect of $\mathrm{HCl}$ addition on $\mathrm{CO}$ oxidation is quiet limited. It is also found that temperature has a promotion effect on $\mathrm{CO}$ oxidation at oxygen-rich condition, thus the inhibition effect of $\mathrm{HCl}$ weakens with the increase of temperature.

The numerical simulation is conducted by CFD software coupled with reduced reaction mechanism involving 12 species and 6 reactions. The simulation results reveal that the reaction $\mathrm{CO}$ $+\mathrm{OH} \leftrightarrow \mathrm{CO}_{2}+\mathrm{H}$ is a crucial reaction for $\mathrm{CO}$ oxidation, and $\mathrm{OH}$ concentration is suppressed when $\mathrm{HCl}$ exists, especially in the noncombustion zone, and results in the inhibition effect on CO oxidation, but the effect is not obvious in combustion zone because of more $\mathrm{OH}$ production under high temperature. The results also indicate that at oxygen-rich conditions, the inhibition effect on $\mathrm{CO}$ oxidation is obvious, and the influence becomes more obvious as the equivalence ratio decreases. However, at chemical equivalent and oxygen-lean conditions, the inhibition effect is not obvious. The reason is that the oxygen is almost consumed, thus the most 
important reaction of $\mathrm{OH}$ production $\mathrm{H}+\mathrm{O}_{2} \leftrightarrow \mathrm{O}+\mathrm{OH}$ is weakened, the production of $\mathrm{OH}$ is inhibited, and thus the effect of $\mathrm{HCl}$ on $\mathrm{OH}$ is limited. It can be seen from the results that the simulation coincides well with the experiment.

\section{Acknowledgments}

Financial support by National Natural Science Foundation of China (Project No. 91530112) is gratefully acknowledged. We also thank Dr. Jingwei Zhang for his test data and Prof. Glarborg in DTU for his help on reactor design.

\section{References}

[1] Yudovich YE, Ketris MP. Chlorine in coal: a review. Int J Coal Geol 2006;67:127-44.

[2] Dunnu G, Maier J, Scheffknecht G. Ash fusibility and compositional data of solid recovered fuels. Fuel 2010;89(7):1534-40.

[3] Teixeira P, Lopes H, Gulyurtlu I, Lapa N, Abelha P. Evaluation of slagging and fouling tendency during biomass co-firing with coal in a fluidized bed. Biomass Bioenergy 2012;39:192-203.

[4] Fang X, Jia L. Experimental study on ash fusion characteristics of biomass. Bioresour Technol 2012;104:769-74.

[5] Luan C, You CF, Zhang DK. An experimental investigation into characteristics and deposition mechanism of high-viscosity coal ash. Fuel 2014;119:14-20.

[6] Fryda L, Sobrino C, Cieplik M, van de Camp WL. Study on ash deposition under oxyfuel combustion of coal/biomass blends. Fuel 2010;89(8):1889-902.

[7] Johansen JM, Jakobsen JG, Frandsen FJ, Glarborg P. Release of $\mathrm{K}, \mathrm{Cl}$, and S during pyrolysis and combustion of high-chlorine biomass. Energy Fuels 2011;25 (11):4961-71.

[8] Bläsing M, Müller M. Influence of pressure on the release of inorganic species during high temperature gasification of coal. Fuel 2011;90(6):2326-33.

[9] Porbatzki D, Stemmler M, Müller M. Release of inorganic trace elements during gasification of wood, straw, and miscanthus. Biomass Bioenergy 2011;35(1): S79-86.

[10] Pisa I, Lazaroiu G. Influence of co-combustion of coal/biomass on the corrosion. Fuel Process Technol 2012;104:356-64.

[11] Wu H, Laurén T, Yrjas P, Vainikka P, Hupa M. Fate of bromine and chlorine in bubbling fluidized bed combustion - formation of alkali halide aerosols. Fuel 2014;128(28):390-5.

[12] Li RD, Kai XP, Yang TH, Sun Y, He YG, Shen SQ. Release and transformation of alkali metals during co-combustion of coal and sulfur-rich wheat straw. Energy Convers Manage 2014;83:197-202.

[13] Kassman H, Pettersson J, Steenari BM, Åmand LE. Two strategies to reduce gaseous $\mathrm{KCl}$ and chlorine in deposits during biomass combustion - injection of ammonium sulphate and co-combustion with peat. Fuel Process Technol 2013;105:170-80,

[14] Roesler JF, Yetter RA, Dryer FL. Detailed kinetic modeling of moist CO oxidation inhibited by trace quantities of $\mathrm{HCl}$. Combust Sci Technol 1992;85:1-22.

[15] Roesler JF, Yetter RA, Dryer FL. The inhibition of the $\mathrm{CO} / \mathrm{H}_{2} \mathrm{O} / \mathrm{O}_{2}$ reaction by trace quantities of $\mathrm{HCl}$. Combust Sci Technol 1992;82:87-100.
[16] Roesler JF, Yetter RA, Dryer FL. Kinetic interactions of $\mathrm{CO}, \mathrm{NO}_{x}$, and $\mathrm{HCl}$ emissions in postcombustion gases. Combust Flame 1995;100:495-504.

[17] Muller C, Kilpinen P, Hupa M. Influence of $\mathrm{HCl}$ on the homogeneous reactions of $\mathrm{CO}$ and NO in postcombustion conditions - a kinetic modeling study. Combust Flame 1998;113:578-88.

[18] Gokulakrishnan P, Lawrence AD. An experimental study of the inhibiting effect of chlorine in a fluidized bed combustor. Combust Flame 1999;116(4):640-52.

[19] Glarborg P. Hidden interactions - trace species governing combustion and emissions. Proc Combust Inst 2007;31:77-98.

[20] Chi Y, Wang B, Yan JH, Ni MJ. Influence of chlorine on methane oxidation. J Environ. Sci. 2009;21:1315-20.

[21] Wang J, Anthony EJ. CO oxidation and the inhibition effects of halogen species in fluidised bed combustion. Combust Theory Model 2009;13(1):105-19.

[22] Wei XL, Wang Y, Liu DF, Sheng HZ. Influence of $\mathrm{HCl}$ on $\mathrm{CO}$ and $\mathrm{NO}$ emissions in combustion. Fuel 2009;88:1998-2003.

[23] Huang YQ, Wang AQ, Li L, Wang XD, Zhang T. Effect of chlorine on $\mathrm{Ir} / \mathrm{CeO}_{2}$ catalyst behavior for preferential CO oxidation. Catal Commun 2010;11:1090-3.

[24] Wang B, Chi Y. Kinetic study on high temperature oxidation of $\mathrm{CO} / \mathrm{H}_{2} / \mathrm{Cl}_{2}$ mixture. In: International conference of digital manufacturing and automation, vol. 1 ; 2010. p. 886-91.

[25] Pelucchi M, Frassoldati A, Faravelli T, Ruscic B, Glarborg P. High-temperature chemistry of $\mathrm{HCl}$ and $\mathrm{Cl}_{2}$. Combust Flame 2015;162:2693-704.

[26] Rasmussen CL, Hanse J, Marshall P, Glarborg P. Experimental measurements and kinetic modeling of $\mathrm{CO} / \mathrm{H}_{2} / \mathrm{O}_{2} / \mathrm{NO}_{x}$ conversion at high pressure. Int $\mathrm{J}$ Chem Kinet 2008;40(8):454-80.

[27] Wang B, Chi Y, Yan JH, Ni MJ. Experimental study on $\mathrm{CCl}_{4} / \mathrm{CH}_{4} / \mathrm{O}_{2} / \mathrm{N}_{2}$ oxidation. Sci China Technol Sci 2010;53(4):1016-22.

[28] Dixon-Lewis G, Marshall P, Ruscic B, Burcat A, Goos E, Cuoci A, et al. Inhibition of hydrogen oxidation by $\mathrm{HBr}$ and $\mathrm{Br}_{2}$. Combust Flame 2012;159:528-40.

[29] Hui X, Zhang C, Xia M, Sung CJ. Effects of hydrogen addition on combustion characteristics of n-decane/air mixtures. Combust Flame 2014;161:2252-62.

[30] Li S, Wei XL, Guo XF. Effect of $\mathrm{H}_{2} \mathrm{O}$ vapor on NO reduction by CO: experimental and kinetic modeling study. Energy Fuels 2012;26:4277-83.

[31] Pagliaro JL, Linteris GT, Sunderland PB, Baker PT. Combustion inhibition and enhancement of premixed methane-air flames by halon replacements. Combust Flame 2015;162:41-9.

[32] Glarborg P, Kubel D, Dam-Johansen K, Chiang HM, Bozzelli JW. Impact of $\mathrm{SO}_{2}$ and $\mathrm{NO}$ on $\mathrm{CO}$ oxidation under post-flame combustion. Int J Chem Kinet 1999;28:773-90.

[33] Wu H, Glarborg P, Frandsen FJ, Dam-Johansen K, Jensen PA, Sander B. Cocombustion of pulverized coal and solid recovered fuel in an entrained flow reactor - general combustion and ash behaviour. Fuel 2011;90(5):1980-91.

[34] Kovács T, Zsély IG, Kramarics A, Turányi T. Kinetic analysis of mechanisms of complex pyrolytic reactions. J Anal Appl Pyrol 2007;79:252-8.

[35] Launder BE, Sharma BI. Application of the energy-dissipation model of turbulence to the calculation of flow near a spinning disc. Lett Heat Mass Transfer 1974;1:131-8.

[36] Magnussen BF. Modeling of pollutant formation in gas turbine combustors based on the eddy dissipation concept. In: Proceedings of 18th international congress on combustion engines. Tianjin, China: International Council on Combustion Engines; 1989.

[37] Pope SB. Computationally efficient implementation of combustion chemistry using in situ adaptive tabulation. Combust Theory Model 1997;1:41-63. 